\title{
Influence of the Bending Momentum Loading of Testing Samples from the Alloy AlSi7Mg0.3 on the Surface Stress State Detected by X-ray Diffraction
}

Ondřej Řidký, Jiří Sobotka

Faculty of Mechanical Engineering, Technical University in Liberec. Studentská 1402/2, 46117 Liberec I. Czech Republic. E-mail: ondrej.ridky@tul.cz, jiri.sobotka@tul.cz

These days are more and more posing claims for the highest quality of castings from the aluminium alloys and for the lowest weight of these castings. Thus for complex material (in this case alloy) utilization it is very important to monitor its behavior both during production (chemical composition, metallographic evaluation of the structure, observance of thermal treatments temperatures, refining and degassing of melt and so on) and also during its loading. This papers deals with the monitoring changes of stress on the testing samples surface arising from the force loading. As a loading there was a bending momentum at the testing samples (rods) from the alloy AlSi7Mg0,3 which was poured into the metal mould after the different thermal treatment methods. Bending momentum increased up to the expressive deformation of the tested sample. Results were also completed by the depth profile of the residual stresses which were measured by means of the $X$-ray diffraction (X-ray tensiometry analysis) namely for all thermal treatment methods. Moreover in the depth profile there was also performed the qualitative evaluation of the structure by the back-reflection Debye-Scherrer method.

Keywords: alloy AlSi7Mg0.3, residual stresses, Debye-Scherrer method

\section{Acknowledgement}

This publication was written at the Technical University of Liberec as part of the Student Grant Contest "SGS 21122" with the support of the Specific University Research Grant, as provided by the Ministry of Education, Youth and Sports of the Czech Republic in the year 2016.

\section{References}

[1] KRAUS, I., GANEV, N. (2004) Technické aplikace difrakční analýzy. Praha: ČVUT. ISBN 80-01-03099-7.

[2] KRAUS, I., GANEV, N., (1995). Difrakční analýzy mechanických napětí. PRAHA: ČVUT, 1995. ISBN 80-0101366-9.

[3] ŘIDKÝ, O., GANEV, N., ZUZÁNEK L., KOLAŘíK, K. (2014). Rentgenografické difrakční stanovení povrchové distribuce makroskopických zbytkových napětí po laserovém svařování s př́ídavným materiálem. In: Strojírenská technologie, Vol. XIX, No.2, FVTM UJEP, Ústí nad Labem pp. 112 - 118 ISSN 1211-4162.

[4] ZUZÁNEK, L., GANEV, N., ŘIDKÝ, O., KOLAŘÍK, K. (2014). RTG difrakční tenzometrická analýza oxidovaných povrchových vrstev ocelí. In: Strojírenská technologie, Vol. XIX, No.2, pp. 136 - 143, FVTM UJEP, Ústí nad Labem, ISSN 1211-4162.

[5] NÁPRSTKOVÁ, N., SVOBODOVÁ, J., CAIS, J. (2013). Modification of AlSi7Mg0.3 alloy by stroncium. In Manufacturing Technology, Vol. 13, No. 3, pp. 373-380 FVTM UJEP, Ústí nad Labem. ISSN 1213-2489.

[6] NOVOTNÝ, J., CAIS, J., NÁPRSTKOVÁ, N.,(2014). Analysis of Aluminium Alloys AlSi7Mg0.3 and AlMg3 by Means of X-Ray Diffraction. In Manufacturing Technology, Vol. 14, No. 3, pp. 392-397 FVTM UJEP, Ústí nad Labem.

[7] BOLIBRUCHOVÁ, D., RICHTÁREK, L. (2016). Possibilities of Using Al-Si-Mg Alloys with Higher Fe Content for Demanding Castings. In Manufacturing Technology, Vol. 16, No. 2, pp. 317 - 323 FVTM UJEP, Ústí nad Labem.

[8] MARTiNOV, M., MÁDL, J., (2016). The Effect of Different Modifiers in AlSi7Mg0.3 Alloy on Built-up Edge Formation in Machining. In Manufacturing Technology, Vol. 16, No. 1, pp. 173 - 178 FVTM UJEP, Ústí nad Labem.

[9] MARTINOV, M., MÁDL, J., (2016). Effect of Different Modifiers and Heat Treatment on Structure, Hardness and Microhardness of AlSi7Mg0.3 Alloy. In Manufacturing Technology, Vol. 15, No. 4, pp. $604-610$ FVTM UJEP, Ústí nad Labem.

[10] PEZDA, J. (2014). Influence of heat treatment parameters on the mechanical properties of hypoeutectic Al-Si-Mg alloy In: Metalurgija, vol. 53, pp. 221 - 224. Croatia. 